\title{
Lean production and work-related musculoskeletal disorders: overviews of international and Swedish studies
}

\author{
Mikael Brännmark ${ }^{\mathrm{a}, \mathrm{b}, *}$ and Malin Håkansson ${ }^{\mathrm{a}}$ \\ ${ }^{a}$ Royal Institute of Technology (KTH), Division of Ergonomics, Stockholm, Sweden \\ ${ }^{\mathrm{b}}$ Linköping University, HELIX VINN Excellence Centre, Linköping, Sweden
}

\begin{abstract}
This paper aimed at summarizing the knowledge of the relationship between Lean and work related musculoskeletal disorders (WMSD), and WMSD risk factors, in manufacturing companies. Literature search processes identified 23 publications studying this, in scientific journals. Eight included measurements of WMSD; three were mostly negative, two showed mixed results, one showed no results and two were mostly positive. Eighteen publications included measurements of WMSD risk factors; seven showed mostly negative results, eight snowed mixed results, two showed mostly positive results and one was inconclusive. Three literature reviews were identified, which studied this question; two were mostly negative, while the third was inconclusive. Also, 12 publications of grey literature studying Lean and WMSD risk factors in Swedish organizations were identified; nine showed mixed results, two showed mostly positive results and one showed mostly negative results. Due to the varying quality and study design of the publications, together with the few identified studies, it is difficult to compare them. The context and the implementation also likely affect the results. The general conclusion was that a Lean implementation may increase the risk of WMSD and risk factors for WMSD, if it is not accompanied with an ergonomic intervention.
\end{abstract}

Keywords: WMSD, working conditions, manufacturing

\section{Introduction}

Lean Production is currently the dominating rationalization concept in the manufacturing industry in Sweden[1-2]. Due to the fast spread of Lean, it is important to study the effects of Lean on work related musculoskeletal disorders (WMSD) and potential risk factors for WMSD, especially since assembly workers in general has a high risk of developing WMSD.

The Swedish context is of special interest for this study, due to the socio-technical tradition that has been influential in the Scandinavian countries, together with a strong union presence and legislation regarding work conditions[2]. These factors likely affect how Swedish companies work with Lean and how the concept affects the employees[3].

\subsection{Lean production}

Lean Production as a management concept was introduced to a wider public through the book The Machine that Changed the World[4]. The concept was not new; earlier publications existed, but through this book, the concept received a large impact[5].

There is no unified definition of Lean[6] and different researchers focus on different aspects of the concept. However, techniques which are often included in Lean's operationalization are small-sized batches (Just in Time-production), 5S/housekeeping, waste reduction (muda), production balancing (jidoka), kanban, standardization, reduction of set-up times and continuous improvements[6].

\footnotetext{
*Corresponding author. E-mail: mikael.brannmark@sth.kth.se
} 


\subsection{Aim of the study}

The aim of the study was to create an overview of the scientific knowledge concerning the relationship between Lean Production (and similar production system designs) and WMSD/risk factors for WMSD. The focus was on manufacturing companies.

A separate search was also made, with the aim of studying how Swedish organizations' work with Lean affects employees.

\section{Method}

Literature searches were performed in Ergonomics Abstract, Pubmed and Business Source Elite ${ }^{l}$. The identified publications references lists were used to find more publications. The search was limited to English and Swedish publications, published after 1980. Conceptual and theoretical papers have been excluded. Studies from non-manufacturing contexts or studies which only focused on specific Lean tools were excluded from the results. Also, studies of Total Quality Management/TQM were excluded, since TQM and Lean are significantly different[6]. However, studies of the Toyota Production System/TPS, Just in Time-philosophy and JiT-manufacturing were included in the results, due to the similarities between TPS and Lean, and since JiT was determined to be an often reoccurring part of Lean.

No excluding definition of Lean has been used during the search process, due to the lack of a unifying definition of the concept. Neither has any means of measuring level of Lean implementation been used, for the same reasons. In order to determine which risk factors that affect mechanical exposure, and consequently, increases the risk for WMSD, Westgaard and Winkel's definition was used[7].

No quality measurement model has been use to assess and rank the identified publications in the search, depending on such factors as study design, etc.

During the search, three literature reviews[7-9] were also identified, which studied directly or indirectly the relationship between Lean and employee effects. Other researchers have also contributed with publications of significance for this overview, which were not identified by the search engines or included in the reference lists of the identified publications.

Since no publications in scientific journals were detected, which studied the relationship between WMSD and Lean in the Swedish manufacturing in- dustry, the choice was made to expand the search to grey literature (conference publications, consultant and union reports, student thesis and dissertations, etc.). This decision was based on Eklund et al.'s[10] argumentation to use the best knowledge available.

\section{Results}

The search process resulted in 23 publications in scientific journals (not including the publications describing Swedish organizations work with Lean). These are presented in table 1 . The few identified papers, together with the differences between the studies, meant that no meta-analysis was possible. The included studies were of varying quality and the Lean interventions were seldom described in detail, making comparisons difficult.

Of the identified publications, eight included measurements regarding WMSD; three showed mostly negative results, two showed mixed results, one showed positive results and two showed no differences between Lean and non-Lean companies. 18 of the found publications studied relevant risk factors for WMSD. Of these, seven showed mostly negative results, eight showed mixed results, two showed positive results and one showed inconclusive results.

Three literature reviews were identified, which studied the relationship between Lean and employee effects[7-9]. Two of these showed mostly negative views of Lean's effects on employee, while one gave an inconclusive view.

The search for publications describing the relationship between Lean and employee effects in Swedish companies resulted in 12 publications (mostly grey literature). Of these, nine showed mixed results, two showed mostly positive results and one showed mostly negative results. Only one publication contained measurements of WMSD frequencies, comparing Lean to non-Lean companies; it showed an increased risk for WMSD in Lean companies, especially for women. However, one of the found publications contained results from non-manufacturing organizations.

When comparing included positive and negative employee results in the Swedish and non-Swedish publications, the ratio between them in the Swedish studies were more even; in the non-Swedish studies, the negative results were more common.

\footnotetext{
${ }^{1}$ Used search words are available on request.
} 


\section{Discussion}

Given the small number of studies, together with their varying quality and study design, and often insufficient descriptions of the Lean interventions, there is not enough basis to make decisive conclusions regarding the connection between Lean and WMSD. However, tentative conclusions were made regarding emerging tendencies in the found publications.

The results shows a tendency for increasing the risk of WMSD, when Lean is implemented, especially if the implementation is not accompanied by an ergonomic intervention program, focused on addressing issues such as reducing monotony and repetitiveness of work.

When it comes to risk factors for WMSD, the results shows that Lean appears to have a tendency to lead to increased work pace, workload, work intensification and stress. However, Lean often, though not always, seem to create positive effects for the employees as well. Consequently, this seems to be in line with Berggren's[11] conclusion, that Lean means worker smarter and harder, not just smarter.

The results from the publications describing employee effects from Swedish companies also shows mixed results, though with a majority of positive effects, at least concerning risk factors for WMSD. However, the grey nature of the studies, together with the low number of publications, means that conclusions from them should be tentative, at best. There is little direct information concerning WMSD, meaning that no conclusions are merited from the publications.

The tendency towards more positive results from Lean, could possibly be explained by the Swedish socio-technical context[3] and a high level of employee participation in the companies' Lean implementations. Also, Saurin and Ferreira's[12] argumentation, that a Lean system which is not fully in place allows for more worker autonomy, which could reduce some of the negative aspects of the Lean, could apply here. The reason is because many of the studied Swedish companies have only implemented some aspects of Lean.

\section{References}

[1] Börnfelt, P.-O., Förändringskompetens på industrigolvet: kontinuerligt förändringsarbete i gränslandet mellan lean production och socioteknisk arbetsorganisation, in
Lastly, we need to keep in mind, as Hasle et al.[8] and Landsbergis et al.'s[9] argue, the importance of how the implementation and context affects the employee results from Lean. Consequently, it is difficult to assess how much of the results that are caused by these factors. Based on this, we argue that it is important to monitor the Lean implementation effects on the employees, in order to reduce problems and capture positive effects.

\section{Conclusions}

While Lean can lead to both positive and negative effects for employees, there is insufficient amount of studies, and they are of varying quality and study design, to make decisive conclusions. Nevertheless, negative results are more frequently reported in the non-Swedish studies, when compared to the grey literature describing studies in Swedish organizations. Thus, it is merited to tentatively conclude that without active ergonomic interventions, the introduction of Lean in a manufacturing setting can create an increased risk for work-related musculoskeletal disorders, though the risk of this in Swedish companies might be lower. However, future research is needed to better understand the relationship between Lean Production and WMSD, both in Swedish and nonSwedish organizations.

\section{Limitations}

The result of the literature searches does not pretense to be covering all existing publications of Lean and WMSD, especially not psychological risk factors.

\section{Acknowledgments}

This study was done as part of a literature overview project, studying the effects from musculoskeletal disorders interventions, financed by the Swedish Work Environment Authority, during the autumn of 2010 and spring of 2011.
Institutionen för arbetsvetenskap. 2006, University of Gothenburg: Gothenburg. p. 221. 
[2] Johansson, J. and L. Abrahamsson, The good work - A Swedish trade union vision in the shadow of lean production. Applied Ergonomics, 2009. 40(4): p. 775-780.

[3] Hampson, I., Lean Production and the Toyota Production System Or, the Case of the Forgoften Production Concepts. Economic and Industrial Democracy, 1999. 20(3): p. 369-391.

[4] Womack, J., D. Jones, and D. Roos, The machine that changed the world: the story of lean production. 1991, New York: HarperPerennial. 323.

[5] Holweg, M., The genealogy of lean production. Journal of Operations Management, 2007. 25(2): p. 420-437.

[6] Pettersen, J., Defining Lean Production - some conceptual and practical issues. The TQM Journal, 2009. 21(2): p. $127-142$.

[7] Westgaard, R.H. and J. Winkel, Occupational musculoskeletal and mental health: Significance of rationalization and opportunities to create sustainable production systems - A systematic review. Applied Ergonomics, 2011. 42(2): p. 261-296.

[8] Hasle, P., et al., Lean and the working environment - a review of the literature. International Journal of Operations and Production Management, unpublished(accepted, but not published).

[9] Landsbergis, P.A., J. Cahill, and P. Schnall, The impact of lean production and related new systems of work organization on worker health. Journal of Occupational Health Psychology, 1999. 4(2): p. 108-130.

[10] Eklund, J., et al., Arbetsmiljöarbete och effekter - en kunskapsöversikt. 2006, Arbetslivsinstitutet.

[11] Berggren, C., Lean Production-The End of History? Work, Employment \& Society, 1993. 7(2): p. 163-188.

[12] Saurin, T.A. and C.F. Ferreira, The impacts of lean production on working conditions: A case study of a harvester assembly line in Brazil. International Journal of Industrial Ergonomics, 2009. 39(2): p. 403-412.

[13] Womack, S.K., T.J. Armstrong, and J.K. Liker, Lean job design and musculoskeletal disorder risk: A two plant comparison. Human Factors and Ergonomics in Manufacturing \& Service Industries, 2009. 19(4): p. 279293.

[14] Brown, G.D. and D. O'Rourke, Lean manufacturing comes to China: a case study of its impact on workplace health and safety. Int J Occup Environ Health, 2007. 13: p. 249-57.

[15] Conti, R., et al., The effects of lean production on worker job stress. International Journal of Operations \& Production Management, 2006. 26(9): p. 1013-1038.

[16] Mehri, D., The Darker Side of Lean: An Insider's Perspective on the Realities of the Toyota Production System. Academy of Management Perspectives, 2006(May): p. 21-42.

[17] Brenner, M.D., D. Fairris, and J. Ruser, "Flexible" Work Practices and Occupational Safety and Health: Exploring the Relationship Between Cumulative Trauma Disorders and Workplace Transformation. Industrial Relations: A Journal of Economy and Society, 2004. 43(1): p. 242-266.

[18] Fairris, D. and M. Brenner, Workplace Transformation and the Rise in Cumulative Trauma Disorders: Is There a Connection? Journal of Labor Research, 2001. XXII(1): p. 15-28.

[19] Schouteten, R. and J. Benders, Lean Production Assessed by Karasek's Job Demand-Job Control Model. Economic and Industrial Democracy, 2004. 25(3): p. 347-373.

Seppälä, P. and S. Klemola, How do employees perceive their organization and job when companies adopt principles of lean production? Human Factors and Ergonomics in Manufacturing \& Service Industries, 2004. 14(2): p. 157-180.

[21] Parker, S., K, Longitudinal effects of lean production on employee outcomes and the mediating role of work characteristics. Journal of Applied Psychology, 2003. 88(4): p. 620-634.

[22] Anderson-Connolly, R., et al., Is Lean Mean? Work, Employment \& Society, 2002. 16(3): p. 389-413.

[23] Bruno, R. and L. Jordan, Lean Production and the Discourse of Dissent. WorkingUSA, 2002. 6(1): p. 108134.

[24] Lewchuk, W., P. Stewart, and C. Yates, Quality of working life in the automobile industry: A Canada-UK comparative study. New Technology, Work and Employment, 2001. 16(2): p. 72-87.

[25] Lewchuk, W. and D. Robertson, Production without Empowerment: Work reorganization from the perspective of motor vehicle workers. Capital \& Class, 1997. 21(3): p. 37-64.

[26] Jackson, P.R. and S. Mullarkey, Lean production teams and health in garment manufacture. Journal of Occupational Health Psychology, 2000. 5(2): p. 231245.

[27] Leclerc, A., et al., Carpal tunnel syndrome and work organisation in repetitive work: a cross sectional study in France. Study Group on Repetitive Work. Occupational and Environmental Medicine, 1998. 55(3): p. 180-187.

[28] Adler, P.S., B. Goldoftas, and D.I. Levine, Ergonomics, Employee Involvement, and the Toyota Production System: A Case Study of NUMMI's 1993 Model Introduction. Industrial and Labor Relations Review, 1997. 50(3): p. 416-437.

[29] Lewchuk, W. and D. Robertson, Working Conditions under Lean Production: A Worker-based Benchmarking Study. Asia Pacific Business Review, 1996. 2(4): p. 60 $-81$.

[30] Jackson, P.R. and R. Martin, Impact of just-in-time on job content, employee attitudes and well-being: a longitudinal study. Ergonomics, 1996. 39(1): p. 1-16.

[31] Nielsen, K.T., How strong are the links between new market conditions, new production principles, and better working conditions? International Journal of Human Factors in Manufacturing, 1996. 6(1): p. 21-28.

[32] Stewart, P. and P. Garrahan, Employee Responses to New Management Techniques in the Auto Industry. Work, Employment \& Society, 1995. 9(3): p. 517-536.

[33] Mullarkey, S., P.R. Jackson, and S.K. Parker, Employee reactions to JIT manufacturing practices: a two-phase investigation. International Journal of Operations \& Production Management, 1995. 15(11): p. 62-79.

[34] Babson, S., Lean or mean: The MIT model and lean production at Mazda. Labor Studies Journal, 1993. 18: p. 3-24.

[35] Berglund, R., Engagemang efterfrågas: Hur tre tillverkande företag söker medverkan från sina medarbetare när de inför Lean, in Institutionen för arbetsvetenskap. 2010, University of Gothenburg: Göteborg.

[36] Brännmark, M., Is Lean No Longer Mean? A Study of the Consequences for Working Conditions in Companies Implementing Lean, in Forum för arbetslivsforsknings konferens (FALF2010): Arbetsliv i förändring. 2010, FALF: Forum för arbetslivsforskning: Malmö, Sweden. 
Oudhuis, M. and A. Olsson, Clashes between Japanese and Swedish cultures - implementing Lean Production in a Japanese owned Swedish company, in Arbetsliv i förändring FALF2010. 2010, Forum för arbetslivsforskning: Malmö, Sweden.

[38] Andersson, C. and J. Liljenvald, Lean-tänkandet i Sverige - en kvantitativ undersökning av medelstora tillverkningsföretag. 2009, Göteborgs universitet, Industriell och finansiell ekonomi: Gothenburg.

[39] Pettersen, J., The implementation of lean: Lost in translation?, in The Nordic Ergonomics Society conference (NES2008): Ergonomics is a lifestyle. 2008, Nordic Ergonomics Society: Reykjavik, Iceland.

[40] Eklund, J. and P. Berglund, Reactions from employees on the implementation of lean production, in Presented at the Nordic Ergonomics Society conference (NES2007): Ergonomics for a future. 2007, Nordic Ergonomics Society: Lysekil, Sweden.
[41] Berglund, P., Turning Japanese?: Kulturella aspekter av införandet av ett nytt produktionssystem. 2007, Linköpings universitet, Institutionen för ekonomisk och industriell utveckling, Industriell arbetsvetenskap: Linköping.

[42] Berglund, R., Smart lean : möjligheter att utnyttja Leankonceptet för att skapa en god arbetssituation. 2006, Mölndal: IVF Industriforskning och utveckling.

[43] IFMetall, Industriarbetarna och lean production. 2003, IF Metall, Arbetsutvecklingsenheten.

[44] Härenstam, A., et al., "Mager och god" eller "Lean and Mean"? Samband mellan organisationsförändringar och arbetsförhållanden, in Smärtgränsen? : en antologi om hälsokonsekvenser i magra organisationer, K. Barklöf, Editor. 2000, Rådet för arbetslivsforskning: Stockholm.

[45] Nilsson, T., Lean Production and White-Collar Work: The Case of Sweden. Economic and Industrial Democracy, 1996. 17(3): p. 447-472.

Table 1

Identified studies describing found relationship between Lean and WMSD, and between Lean and risk factors for WMSD.

$(+)=$ high, increasing; $(+$ ? $)=$ weak positive connection; $(-)=$ decreasing, low; $(-?)=$ weak negative connection; $(+/-)=$ both increasing and decreasing; $(0)=$ no effect/no connection. The studies are presented in chronological order, starting with the most recent ones.

\begin{tabular}{|c|c|c|}
\hline $\begin{array}{l}\text { Author, year, industry, study } \\
\text { design, studied change }\end{array}$ & $\begin{array}{l}\text { Effects on } \\
\text { WMSD \& health }\end{array}$ & Effects on risk factors for WMSD \\
\hline $\begin{array}{l}\text { Saurin \& Ferreira } 2009[12] \\
\text { Manufacturing of harvesters, } \\
\text { Brazil, interviews, question- } \\
\text { naires, feedback meeting, no } \\
\text { control group, several Lean tools } \\
\text { implemented since } 2001 .\end{array}$ & $\begin{array}{l}\text { Pain/discomfort at } \\
\text { a moderate level; } \\
\text { unchanged by } \\
\text { Lean }(0) \text {. }\end{array}$ & $\begin{array}{l}\text { Increased work pace/load (+) } \\
\text { Decreased time for brakes }(-) \text {. } \\
\text { Increased pressure from superiors to achieve goals; still, the employees were } \\
\text { fairly satisfied with the relationship with the managers }(+) \\
\text { General working conditions had improved }(+) \\
\text { Moderately stressed, which had increased from Lean }(+) \\
\text { Improved autonomy }(+)\end{array}$ \\
\hline $\begin{array}{l}\text { Womack et al. 2009[13] } \\
\text { Car manufacturing, USA. Com- } \\
\text { parison between } 56 \text { work stations } \\
\text { in a Lean \& traditional factory. }\end{array}$ & $\begin{array}{l}\text { The Lean factory } \\
\text { had reduced the } \\
\text { number of injuries } \\
\text { by } 19 \% \text { between } \\
2000-2006(-) \text {. }\end{array}$ & $\begin{array}{l}\text { Repetitive work increased }(+) \\
\text { Lower use of force }(-) \\
\text { No difference in work postures }(0) \\
\text { In both factories, } 60 \% \text { of the work was classified as having risk for hand related } \\
\text { problems; no significant differences between the two factories. }\end{array}$ \\
\hline $\begin{array}{l}\text { Brown \& O'Rourke 2007[14] } \\
\text { Shoe manufacturing, China. Case } \\
\text { study: } 27 \text { questionnaires \& focus } \\
\text { groups ( } 20 \text { persons), no control } \\
\text { group. Lean was introduced } \\
\text { approximately } 1 \text { year ago; used } \\
\text { tools was JiT, reduced invento- } \\
\text { ries, etc. }\end{array}$ & & $\begin{array}{l}\text { Increased pressure on the production }(+) \\
\text { Increased individual stress }(+) \\
\text { Almost all of the respondents reported that the work conditions had improved } \\
\text { during the recent year. }(+) \\
\text { Stress was related to worry of not reaching set goals, unrealistic goal setting, too } \\
\text { high work pace, too much work, unfair supervisor }\end{array}$ \\
\hline $\begin{array}{l}\text { Conti et al. 2006[15] } \\
\text { Manufacturing, UK, } 1391 \text { ques- } \\
\text { tionnaires, assessed level of Lean } \\
\text { (1-5) for } 10 \text { Lean tools \& tested } \\
21 \text { hypothesis related to stress. }\end{array}$ & & $\begin{array}{l}\text { Reversed u-shaped connection between stress and level of Lean implementation: } \\
\text { low level of Lean, increased stress, while reduced stress at high level of imple- } \\
\text { mentation of Lean }(+/-) \\
\text { The stress is increased by work intensification, overtime, doing the work for } \\
\text { personnel missing for sick leave, lack of tools, ergonomic difficulties and shame } \\
\text { for defect products; stress was reduced through participation, teamwork and } \\
\text { support in the work situation. }\end{array}$ \\
\hline $\begin{array}{l}\text { Mehri 2005[16] } \\
\text { Car manufacturing, Japan, for- } \\
\text { mer employee of studied compa- } \\
\text { ny. } 75 \text { interviews. }\end{array}$ & & Perceived work load was high $(+)$ \\
\hline $\begin{array}{l}\text { Brenner et al. 2004[17] } \\
\text { Fairis \& Brenner 2001 [18] } \\
\text { Industrial setting, statistics from } \\
\text { BLS, combined with investiga- } \\
\text { tion of the occurrence of TQM, } \\
\text { JiT, teams and Quality Circles. }\end{array}$ & $\begin{array}{l}\text { Correlation be- } \\
\text { tween cumulative } \\
\text { trauma disord- } \\
\text { ers/CTD and } \\
\text { Quality Cir- } \\
\text { cles/QC, and } \\
\text { between CTDS \& } \\
\text { JiT (+); worse }\end{array}$ & \\
\hline
\end{tabular}




\begin{tabular}{|c|c|c|}
\hline & $\begin{array}{l}\text { when JiT \& QC } \\
\text { was combined }(+) \text {. } \\
\text { No connection } \\
\text { between CTD \& } \\
\text { TQM, \& between } \\
\text { CTD \& team. }(0)\end{array}$ & \\
\hline $\begin{array}{l}\text { Schouten \& Benders 2004[19] } \\
\text { Bike assembly, Holland } \\
\text { Observations and } 63 \text { employee } \\
\text { questionnaires, used tools were } \\
\text { JiT, quality control, TPM, stan- } \\
\text { dardization, 5S, andon, kaizen } \\
\text { and reduced inventories. }\end{array}$ & $\begin{array}{l}\text { Workers: } \\
\text { Few problems } \\
\text { with health/ phys- } \\
\text { ical reactions (-) }\end{array}$ & $\begin{array}{l}\text { Workers: } \\
\text { Autonomy limited (-) } \\
\text { Support from supervisors or other departments had decreased }(-) \\
\text { High dissatisfaction with work content }(-) \\
\text { Short work cycles }(-) \\
\text { Overview of work limited (-) } \\
\text { Need for resting high }(+) \\
\text { Satisfactory means to solve problems in work, due to support from workers }(+) \\
\text { Work satisfaction limited }(-) \\
\text { Supervisors: } \\
\text { Better working conditions, when compared to workers }(+)\end{array}$ \\
\hline $\begin{array}{l}\text { Seppälä \& Klemola 2004[20] } \\
\text { Manufacturing companies, Fin- } \\
\text { land. Cross-sectional study, } 525 \\
\text { questionnaires,4 companies, } \\
\text { introduced Lean tools were JiT, } \\
\text { "pull" production, etc. }\end{array}$ & & $\begin{array}{l}\text { Increased perceived work pace }(+) \\
\text { Increased perceived work control }(+) \\
\text { Increased stress for the white-collar workers }(+)\end{array}$ \\
\hline $\begin{array}{l}\text { Parker 2003[21] } \\
\text { Automotive manufacturer, UK. } \\
368 \text { questionnaires, } 3 \text { years after } \\
\text { Lean was implemented. Control } \\
\text { group used. Introduced Lean } \\
\text { tools: assembly lines, Lean- } \\
\text { teams, process development } \\
\text { teams, standardization, reduced } \\
\text { inventories, "pull-production", } \\
\text { manufacturability. The assem- } \\
\text { blers in the assembly line were } \\
\text { not included in the Lean teams. }\end{array}$ & & $\begin{array}{l}\text { Work related depression increased with assembly lines and standardization }(+) \\
\text { Reduced confidence to own ability to perform a broader role, such as making } \\
\text { suggestions for improvements }(-) \\
\text { Worker involvement in the workplace was reduced }(-) \\
\text { Participation was unchanged for those participating in Lean-teams }(0) \text {, while it } \\
\text { increased for the employees in the technical support group }(+) \\
\text { No changes in workload or work related worry for lean team }(0) \text {; increased for } \\
\text { assembly lines }(+) \text {. } \\
\text { Reduced participation in the work process and usage of skills, and reduced } \\
\text { autonomy, were contributing factors for negative effects from Lean. }\end{array}$ \\
\hline $\begin{array}{l}\text { Andersen-Connolly et al. } \\
\text { 2002[22] } \\
\text { Manufacturing, USA. Longitu- } \\
\text { dinal questionnaire study (1997 } \\
\& 1999), 1244 \text { questionnaires. } \\
\text { Studying effects from restructur- } \\
\text { ing, outsourcing, reduced inven- } \\
\text { tories, simplified processes \& } \\
\text { cross-functional teams. }\end{array}$ & & $\begin{array}{l}\text { Employees: } \\
\text { Reduced health related to work intensity, competence and teamwork (-). } \\
\text { Improved health related to autonomy }(+) \\
\text { Management: } \\
\text { Reduced health related to work intensity and autonomy }(-) \text {. } \\
\text { Improved health related to teamwork and work skill }(+) \text {. }\end{array}$ \\
\hline $\begin{array}{l}\text { Bruno \& Jordan 2002[23] } \\
\text { Car manufacturing (Chrysler), } \\
\text { USA. Longitudinal study (1989 } \\
\text { \& 1997). Lean tools imple- } \\
\text { mented: quality circles, team- } \\
\text { work, kaizen and andon. }\end{array}$ & & $\begin{array}{l}\text { The perceived work environment and job satisfaction was reduced (-) } \\
\text { Most of the employees felt that quality circles \& teamwork gave very little }(0) \text {. } \\
\text { However, difficult to assess if the changes are caused by Lean or other factors, } \\
\text { such as distrust of the management or failed expectations on the work. }\end{array}$ \\
\hline $\begin{array}{l}\text { Lewchuk \& Robertson } \\
\text { 2001[24] } \\
\text { Lewchuk \& Robertson } \\
\text { 1997[25] } \\
\text { Car manufacturing companies, } \\
\text { Canada. Comparing } 4 \text { companies } \\
\text { of differing level of Lean imple- } \\
\text { mentation. Highest level had GM } \\
\text { \& CAMI; lowest had Ford \& } \\
\text { Chrysler. } 2424 \text { questionnaire. }\end{array}$ & $\begin{array}{l}\text { Working with } \\
\text { pain, exposure to } \\
\text { muscular fatigue } \\
\& \text { WMSD }(+?)\end{array}$ & $\begin{array}{l}\text { Perceived work pace higher at GM }(+) \\
\text { Highest perceived work load at GM }(+) \\
\text { Possibility of varying work rhythm and talking during the work was lowest at } \\
\text { GM, highest at CAMI }(+/-) \\
\text { Difficulty of finding replacement for bathroom brakes were approximately the } \\
\text { same (0) }\end{array}$ \\
\hline $\begin{array}{l}\text { Jackson \& Mullarkey 2000[26] } \\
\text { Garment manufacture. Compar- } \\
\text { ing normal production line \& cell } \\
\text { manufacturing. }\end{array}$ & & $\begin{array}{l}\text { Job satisfaction unchanged }(0) \\
\text { Work related effort unchanged }(0)\end{array}$ \\
\hline Leclerc et al. 1998[27] & Odds ratio 2,24 & \\
\hline
\end{tabular}




\begin{tabular}{|c|c|c|}
\hline $\begin{array}{l}\text { Assorted manufacturing compa- } \\
\text { nies, France. Cross-sectional } \\
\text { study of JiT-production, with } \\
\text { reference group }\end{array}$ & $\begin{array}{l}\text { for developing } \\
\text { CTD in compa- } \\
\text { nies working with } \\
\text { JiT }(+) \text {. }\end{array}$ & \\
\hline $\begin{array}{l}\text { Adler et al. 1997[28] } \\
\text { Car manufacturing (NUMMI), } \\
\text { USA. Longitudinal case study, } \\
\text { investigating the ergonomic } \\
\text { situation during launches of new } \\
\text { car models in } 1993 \text { and } 1995 .\end{array}$ & $\begin{array}{l}\text { High frequency of } \\
\text { reported injuries } \\
\text { during launch of } \\
\text { car model }(+) \text {. } \\
\text { Injuries reduced } \\
\text { after ergonomic } \\
\text { intervention pro- } \\
\text { gram }(-) \text {. }\end{array}$ & \\
\hline $\begin{array}{l}\text { Lewchuk \& Robertson } \\
\text { 1996[29] } \\
16 \text { suppliers to car manufacturing } \\
\text { companies, Canada. } 2 \text { Lean } \\
\text { companies, } 4 \text { companies who had } \\
\text { initiated Lean, } 8 \text { traditional com- } \\
\text { panies \& } 2 \text { explorative compa- } \\
\text { nies. } 1670 \text { questionnaires }\end{array}$ & $\begin{array}{l}\text { Working with } \\
\text { pain similar in } \\
\text { Lean \& traditional } \\
\text { companies }(0) \text {. } \\
\text { Working with } \\
\text { pain lower at } \\
\text { companies initiat- } \\
\text { ing Lean }(-)\end{array}$ & $\begin{array}{l}\text { Perceived work load higher, and the perceived increase was higher, when com- } \\
\text { paring the Lean companies to the traditional companies }(+) \\
\text { Perceived work load and uncomfortable working postures was lower in compa- } \\
\text { nies initiating Lean compared to traditional companies; the perceived increase in } \\
\text { work load was also lower (-) } \\
\text { Uncomfortable work postures, fatigue after work and tension during work was } \\
\text { similar in Lean \& traditional companies }(0) \text {; however, the perceived increase of } \\
\text { fatigue after work and tension during work was higher in the Lean company }(+)\end{array}$ \\
\hline $\begin{array}{l}\text { Jackson \& Martin 1996[30] } \\
\text { Electronics manufacturing, UK } \\
\text { Comparison between JiT assem- } \\
\text { bly line (small batches, job rota- } \\
\text { tion, simplified processes, pull } \\
\text { production, inspection of own } \\
\text { work) \& traditional non-JiT line. } \\
44 \text { questionnaires before \& after. }\end{array}$ & & $\begin{array}{l}\text { Work load higher with JiT (+) } \\
\text { Work satisfaction decreased with JiT (-) } \\
\text { Psychological stress unchanged (0) } \\
\text { Chance of influencing work pace and which order in which job task are done in } \\
\text { the work process decreased with JiT (-) }\end{array}$ \\
\hline $\begin{array}{l}\text { Nielsen 1996[31] } \\
6 \text { manufacturing companies, } 1 \text { in } \\
\text { process industry, Denmark } \\
\text { Studied production systems } \\
\text { inspired by Japanese manage- } \\
\text { ment (sporadic implementation } \\
\text { of JiT, other Lean tools in parts } \\
\text { of the factories). Interviews with } \\
\text { persons from all levels of com- } \\
\text { panies, observations from } 3 \\
\text { companies, } 150 \text { questionnaires } \\
\text { from } 4 \text { companies }\end{array}$ & & $\begin{array}{l}\text { Few or no changes in competence requirements }(0) \\
\text { Integration of quality control in the normal job design was perceived as creating } \\
\text { better job satisfaction }(+) \\
\text { No changes in worker autonomy, though in one company, the autonomy in- } \\
\text { creased since workers could see the production planning one month ahead, } \\
\text { instead of only } 1-2 \text { weeks }(0) \\
\text { Physical work load unchanged }(0) \\
\text { The general conclusion was that those jobs who had the best working conditions } \\
\text { from the start perceived some improvements }(+) \text {, while it was unchanged in the } \\
\text { jobs with repetitive and unqualified jobs }(0) \text {. } \\
\text { The results and basis for the conclusions were not clearly presented in the paper. }\end{array}$ \\
\hline $\begin{array}{l}\text { Stewart \& Garrahan 1995[32] } \\
\text { Car manufacturers, USA \& UK } \\
4 \text { factories; } 140 \text { questionnaires. } \\
\text { Used tools: teamwork, conti- } \\
\text { nuous improvements, etc. }\end{array}$ & & $\begin{array}{l}\text { Physical fatigue from work increased }(+) \\
\text { Mental fatigue from work increased }(+) \\
\text { Job satisfaction unchanged, or slight decrease }(0 /-)\end{array}$ \\
\hline $\begin{array}{l}\text { Mullarkey et al. 1995[33] } \\
\text { Electronics manufacturing, UK } \\
\text { Prospective study of JiT \& TQM. }\end{array}$ & & $\begin{array}{l}\text { Stress showed no connection to JiT (0) } \\
\text { Work satisfaction increased with JiT }(+) \\
\text { Work pace/demands had a weak reversed connection with JiT (-?) }\end{array}$ \\
\hline $\begin{array}{l}\text { Babson 1993[34] } \\
\text { Car manufacturing (Mazda \& } \\
\text { Ford), USA. Case study, } 2380 \\
\text { questionnaires } 3 \text { years after Lean } \\
\text { implemented. No control group. }\end{array}$ & & $\begin{array}{l}\text { Perceived work demands increased }(+) \\
\text { Perceived work control decreased }(-) \\
\text { A high proportion of the respondents believed that they would be injured/worn } \\
\text { out before pension, with the current work intensity }(+)\end{array}$ \\
\hline
\end{tabular}

Table 2

Identified studies describing the relationship between Lean and risk factors for WMSD in Swedish companies. $(+)=$ high, increasing; $(+?)=$ weak positive connection; $(-)=$ decreasing, low; $(-?)=$ weak negative connection; $(+/-)=$ both increasing and decreasing; $(0)=$ no effect/no connection. The studies are presented in chronological order, starting with the most recent ones.

\begin{tabular}{|l|l|l|}
\hline $\begin{array}{l}\text { Author, year, type of publi- } \\
\text { cation, study design, studied } \\
\text { change }\end{array}$ & $\begin{array}{l}\text { Effects on WMSD } \\
\text { \& health }\end{array}$ & Effects on risk factors for WMSD \\
\hline $\begin{array}{l}\text { Berglund 2010[35] } \\
\begin{array}{l}\text { Dissertation. Qualitative study, } \\
3 \text { companies working with }\end{array}\end{array}$ & $\begin{array}{l}\text { Increased job satisfaction, through employee involvement in work with conti- } \\
\text { nuous improvements (CI) and problem solving (PS) (+) } \\
\text { Lean. }\end{array}$ & $\begin{array}{l}\text { Reduced job satisfaction, due to increased control and steering of the work (-) } \\
\text { Reduced cycle times (-.) }\end{array}$ \\
\hline
\end{tabular}




\begin{tabular}{|c|c|c|}
\hline $\begin{array}{l}\text { Brännmark 2010[36] } \\
\text { Conference paper. Qualitative } \\
\& \text { quantitative study (41 inter- } \\
\text { views, } 82 \text { questionnaires), } 8 \\
\text { companies. Lean tools: value } \\
\text { stream mapping, standardiza- } \\
\text { tion, } 5 \mathrm{~S} \text {, improvement groups } \\
\& \text { set-up time reduction. }\end{array}$ & & $\begin{array}{l}\text { Improved working environment }(+) \\
\text { Increased stress }(+)\end{array}$ \\
\hline $\begin{array}{l}\text { Oudhuis \& Olsson 2010[37] } \\
\text { Conference paper. Qualitative } \\
\text { case study of large company } \\
\text { implementing Lean. }\end{array}$ & & $\begin{array}{l}\text { Improved work environment }(+) \\
\text { Increased job satisfaction, through employee involvement in CI \& PS }(+) \\
\text { Increased stress due to more monotonous and stressful work }(+) \\
\text { Reduced cycle times }(-) \\
\text { Reduced job satisfaction, due to standardization making work more boring }(-) \\
\text { Increased workload, due to increased demands for working overtime }(+) \\
\text { The positive effects of Lean only affect a portion of the employees. }\end{array}$ \\
\hline $\begin{array}{l}\text { Andersson \& Liljenvald } \\
\mathbf{2 0 0 9}[38] \\
\text { Student thesis. Questionnaire } \\
\text { study of common elements in } \\
\text { manufacturing companies' } \\
\text { Lean work. }\end{array}$ & & $\begin{array}{l}\text { Increased job satisfaction, through increased group autonomy and employee } \\
\text { empowerment, is common aspects in Swedish medium sized manufacturing } \\
\text { companies work with Lean }(+?)\end{array}$ \\
\hline $\begin{array}{l}\text { Pettersen } \mathbf{2 0 0 8}[39] \\
\text { Conference paper. Qualitative } \\
\text { study, } 2 \text { companies implement- } \\
\text { ing Lean. Lean-tools: daily } \\
\text { steering, visualization \& 5S. }\end{array}$ & & $\begin{array}{l}\text { Improved work environment }(+) \\
\text { Improved job satisfaction, due to improved communication between depart- } \\
\text { ments }(+)\end{array}$ \\
\hline $\begin{array}{l}\text { Eklund \& Berglund 2007[40] } \\
\text { Conference paper. Qualitative } \\
\text { study, } 2 \text { companies implement- } \\
\text { ing Lean (one turbine manu- } \\
\text { facturer \& one lift truck } \\
\text { manufacturer). }\end{array}$ & & $\begin{array}{l}\text { Improved working environment }(+) \\
\text { Lowered workload, due to slower and more even work pace }(+) \\
\text { Increased job satisfaction, through employee involvement in CI \& PS }(+) \\
\text { Increased stress, caused by more monotonous work, assembly lines and in- } \\
\text { creased work pace }(+) \\
\text { Reduced job satisfaction, due reduced contacts with other employees }(-) \\
\text { Reduced cycle times }(-) \\
\text { Increased workload, due to demands to work more overtime and to work in } \\
\text { shift, not just day time }(+)\end{array}$ \\
\hline $\begin{array}{l}\text { Berglund 2007[41] } \\
\text { Student thesis. Qualitative } \\
\text { study of company implement- } \\
\text { ing Lean. }\end{array}$ & & $\begin{array}{l}\text { Improved working environment }(+) \\
\text { Reduced workload, due to slower and more even work pace }(-) \\
\text { Increased job satisfaction, through employee involvement in CI \& PS }(+) \\
\text { Reduced job satisfaction from increased control, steering and standardization }(-)\end{array}$ \\
\hline $\begin{array}{l}\text { Börnfelt 2006[1] } \\
\text { Dissertation. Qualitative study } \\
\text { of } 3 \text { companies' Lean work. }\end{array}$ & & $\begin{array}{l}\text { Increased job satisfaction, through employee involvement in CI \& PS }(+) \\
\text { Increased job demands, due to competition between work groups and "shame" } \\
\text { techniques, and the employees are expected to monitor each other }(+)\end{array}$ \\
\hline $\begin{array}{l}\text { Berglund 2006[42] } \\
\text { Consultant report. Interviews } \\
\text { with managers from } 22 \text { com- } \\
\text { panies working with Lean, plus } \\
\text { work place studies in } 5 \text { com- } \\
\text { panies. }\end{array}$ & & $\begin{array}{l}\text { Reduced heavy lifting and improved work postures }(-) \\
\text { Employees can take shorter brakes when needed }(+) \\
\text { Work pace is slow and leveled }(-) \\
\text { Increased job satisfaction, through employee involvement in CI \& PS }(+) \\
\text { Two of the five studied work places were assess as needing improvements in } \\
\text { work postures, increased work variation and reductions of heavy lifting. }\end{array}$ \\
\hline $\begin{array}{l}\text { IF Metall 2003[43] } \\
\text { Union report. Questionnaire } \\
\text { study (17 } 000 \text { respondents) of } \\
\text { Lean's impact on working } \\
\text { conditions. }\end{array}$ & $\begin{array}{l}\text { WMSD frequency } \\
\text { higher for em- } \\
\text { ployees in Lean } \\
\text { companies; highest } \\
\text { risk for women }(+)\end{array}$ & $\begin{array}{l}\text { Increased workload, due to insufficient staffing }(-) \\
\text { Reduced cycle times }(-) \\
\text { Increased perceived stress by over } 70 \% \text { of respondents }(+) \\
\text { The positive effects of Lean only affect a portion of the employees. }\end{array}$ \\
\hline $\begin{array}{l}\text { Härenstam et al. } \mathbf{2 0 0 0}[44] \\
\text { Book chapter. Mixed qualita- } \\
\text { tive \& quantitative study, } 72 \\
\text { organizations \& } 210 \text { respon- } \\
\text { dents. Comparing the effects } \\
\text { on work conditions in Lean \& } \\
\text { non-Lean organizations. }\end{array}$ & & $\begin{array}{l}\text { Work postures increasing the risk of WSMD was higher }(+) \\
\text { Increased workload }(+) \\
\text { Increased stress, due to increased number of indirect obstacles in the work }(+) \\
\text { Less negative effects, compared to non-Lean organizations, on influence and } \\
\text { stimulation in the work situation }(-) \\
\text { The negative effects are especially negative for women. }\end{array}$ \\
\hline $\begin{array}{l}\text { Nilsson 1996[45] } \\
\text { Peer review article. Discusses } \\
\text { Lean \& how it affects white- } \\
\text { collar workers in Sweden }\end{array}$ & & $\begin{array}{l}\text { White-collar workers: } \\
\text { Broader work duties }(+) \\
\text { Increased workload, due to understaffing }(+)\end{array}$ \\
\hline
\end{tabular}

